\title{
PENILAIAN PIHAK INDUSTRI TERHADAP TINGKAT KEMAMPUAN KERJA MAHASISWA JURUSAN PENDIDIKAN TEKNIK MESIN FT UNIVERSITAS NEGERI MEDAN DALAM MENGIKUTI PRAKTEK KERJA INDUSTRI.
}

\author{
Pudin Saragih \\ Pudinsaragih123@gmail.com
}

\begin{abstract}
Abstrak
Penelitian ini bertujuan untuk melihat penilaian pihak industri khususnya pembimbing terhadap kemampuan kerja dari para mahasiswa peserta praktek kerja lapangan industri Jurusan Pendidikan Teknik Mesin FT Unimed Medan priode 2013 dan 2014. Metode penelitian yang digunakan adalah Expost Facto. Populasi adalah seluruh pembimbing mahasiswa dari pihak industri. Jumlah sampel adalah seluruh populasi penelitian (penelitian populasi). Untuk menjaring data digunakan angket yang telah lebih dulu divalidasikan dengan pihak ahli (expert judgement), sedang reliabilitas angket tidak dicari. Kemudian untuk menganalisis data hasil penelitian digunakan statistik deskriptif. Dari hasil analisis data diperoleh kesimpulan bahwa kecenderungan kemampuan kerja mahasiswa peserta praktek di industri dinilai "kurang" oleh pihak industri (64,20\%). Selanjutnya kecenderungan kemampuan kerja para mahasiswa ditinjau dari tiap-tiap aspek adalah sebagai berikut : (1) aspek pengetahuan kerja sebesar $72 \%$ (cukup); (2) aspek kreativitas kerja sebesar 53\% (kurang); (3) aspek kecepatan kerja sebesar 68\% (kurang); (4) aspek kualitas hasil kerja sebesar 67\% (kurang) dan (5) aspek disiplin dan sikap kerja sebesar 61\% (kurang). Di samping itu ditemukan pula bahwa pelaksanaan kegiatan peraktek terutama yang menyangkut disiplin kerja kurang mendapat perhatian dari para mahasiswa.
\end{abstract}

Kata kunci : Pengetahuan, Kreativitas, Kualitas, Kecepatan, Disiplin dan Sikap, serta Kemampuan Kerja.

\section{Pendahuluan}

Dibukanya program D3 Teknik Mesin di IKIP Medan tahun 1998, diharapkan dapat meningkatkan kompetensi profesional (bidang keteknikan) bagi mahasiswa S1 Pendidikan Teknik Mesin. Kompetensi mahasiswa dibidang keteknikan baik S1 Pendidikan Pend.Tek Mesin maupun D3 Teknik Mesin dirancang setara atau sama, dan perbedaan kompetensi hanya pada bidang kependidikan. Sejalan dengan itu, mahasiswa FT Unimed Jurusan Teknik Mesin memiliki kurikulum yang sama untuk tingkat D3 dan S1, salah satu diantaranya adalah mata kuliah Praktek Kerja Lapangan Industri (PKLI).

Kesempatan untuk melaksanakan praktek kerja industri (PKLI) yang telah dimuat secara terprogram dalam kurikulum, dimaksudkan agar mereka benar-benar dapat 
merasakan, mengalami praktek kerja diluar dari kampus. Dengan melakukan kegiatan tersebut mereka diharapkan dapat membawa pengalamannya kedalam kegiatan mengajar bila menjadi guru, sedangkan bagi mereka yang berminat ke dunia industri, mereka telah memiliki bekal pengalaman mengenai dunia kerja yang sesungguhnya.

Praktek kerja lapangan industri di berikan pada semester VII. Ini berarti bahwa sebelum melaksanakan PKLI, mahasiswa telah dibekali seperangkat keterampilan baik teori maupun praktek sesuai bidangnya masing-masing. Bekal pengetahuan dan keterampilan yang diperoleh dilingkungan kampus diharapkan dapat diaplikasikan dalam proses kegiatan pada dunia usaha dan industri.

Untuk mengetahui sejauh mana bekal yang telah diperoleh mahasiswa dilingkungan kampus sesuai dengan tuntutan pihak industri, maka perlu dilakukan suatu penelitian. Salah satu cara untuk mengungkap hal tersebut adalah dengan mengumpulkan berbagai penilaian/pendapat atau komentar dari pihak industri yang langsung bertindak sebagai pembimbing praktek di industri. Penilaian atau pendapatpendapat tersebut meliputi kemampuan kerja, baik teori maupun praktek serta sikap kerjanya dalam kegiatan praktek kerja industri.

Kemampuan kerja dapat dipandang sebagai kecakapan kerja berupa bagian dari ranah kognitif, afektif, dan psikomotorik (Edward, 1985). Menurut Braden (1970), seorang dikatakan memiliki kemampuan kerja bila dia telah mamiliki penguasaan baik dalam bentuk teori kerja dan sekaligus dapat mempraktekkan teori tersebut untuk bekerja. Djoemadi (1988), berpendapat seseorang dikatakan telah mamiliki kemampuan kerja jika mereka telah menguasai pengetahuan kerja maupun keterampilan kerja. Pengetahuan kerja dimaksud meliputi pengetahuan bahan, pengetahuan alat-alat ukur, pengetahuan gambar, teori kerja mesin, plat, las, tempa, keselamatan kerja dan pengetahuan tentang perawatan alat dan perkakas. Sejalan dengan hal tersebut, Sugiyono (1990) mengatakan, tiga aspek kemapuan yaitu aspek pengetahuan, keterampilan dan sikap dapat digolongkan menjadi : pengetahuan kerja, kecepatan kerja, kualitas kerja,dan disiplin serta sikap kerja. Dengan demikian bagaimanakah penilaian atau pendapat para pihak industri terhadap unjuk kerja mahasiswa pada ke lima faktor di atas setelah dibekali dibangku kuliah, tampaknya memerlukan suatu jawaban yang jelas melalui penelitian.

Berdasarkan uraian di atas, penelitian ini dimaksud untuk mengetahui penilaian pihak industri tentang kemampuan para mahasiswa peserta PKLI Jurusan Teknik Mesin FT Unimed yang meliputi : pengetahuan kerja, kecepatan kerja kreativitas kerja, kualitas kerja, disiplin dan sikap kerja selama melaksanakan kegiatan PKLI tersebut.

Bekal pengetahuan yang dimiliki mahasiswa dari bangku kuliah akan ditunjukkan di dunia industri tempat melaksanakan PKLI. Menurut Thorndike sebagaimana dikutip Bower (1981) dalam teori of learning , " Transfer of Training "akan terjadi bila mana hal-hal yang telah 
dipelajari dengan hal-hal yang akan ditempuh atau dikerjakan terdapat unsurunsur yang identik. Bertitik tolak dari hal tersebut, maka agar mahasiswa dapat melaksanakan PKLI dengan baik, perlu diberikan bekal pengetahuan yang cukup memadai berkaitan dengan keadaan yang ada di industri. Dengan adanya bekal pengetahuan tersebut, akan mempermudah dalam pengembangan diri bagi pera peserta PKLI, dalam upaya membentuk sumber daya manusia yang memiliki kemampuan bekerja yang baik.

Kreativitas adalah suatu kemampuan untuk menciptakan atau kemampuan daya cipta dengan cara mencari kesimpulan, menerka memformulasikan, hipotesishipotesis dan mengujinya, memungkinkan perubahan-perubahan dan akhirnya mengkomunikasikan hasilnya (Torence 1962, Depdikbud 1988). Amin (1980), menyatakan kreativitas adalah sebagai pola berfikir atau ide spontan atau imajinatif yang mencirikan hasil artistik penemuanpenemuan ilmiah, dan penciptaanpenciptaan mekanik. Selanjutnya menurut Leighbody (1968), dalam kaitannya dengan kreativitas kerja bidang pemesinan dapat dilihat dari : 1) kemampuan dalam menganalisis pekerjaan dan perencanaan langkah-langkah mulai dari saat dikerjakan sampai selesai, 2) kemampuan dalam menggunakan berbagai informasi untuk digunakan sebagai pertimbangan dalam bekerja, dan 3) kemampuan untuk membuat putusan dengan menggunakan teori yang diperolehnya. Dari beberapa pendapat diatas, disimpulkan bahwa kreativitas adalah kemampuan menerapkan pengetahuan dan keterampilan yang dimiliki secara spontan dan sistematis. Menurut Wetik (1986), kecepatan kerja dapat dilihat dari keterampilan produksi yang tinggi, dengan kata lain seorang tenaga kerja dikatakan memiliki kecepatan kerja yang tinggi bila mampu menghasilkan atau menyelesaikan produk yang ditentukan dalam satuan waktu yang lebih singkat (Ravianto,J,1985).

Dari pendapat tersebut dapat diartikan bahwa kualitas suatu produk akan terkait pada kemampuan serta keyakinan para pengguna hasil produksi tersebut. Disiplin adalah pengendalian terhadap keinginan tentang suatu, sehingga sesorang bertindak mengikuti aturan yang berlaku (Godwin, 1975). Lebih lanjut dikatakan bahwa disiplin akan terpengaruh terhadap pembentukan sikap. Berkaitan dengan sikap dimaksud, Mar'at (1981), mengemukakan bahwa sikap merupakan suatu produk dari proses sosialisasi dan akan bereaksi dengan rangsangan yang diterimanya. Dari kutipan ini dapat diketahui bahwa sikap akan timbul apabila setelah berlangsungnya suatu peoses. Perubahan sikap terjadi apabila individu mendapat keadaan dan syarat-syarat yang memungkinkan atau mempermudah berubahan sikap itu. Kelman sebagaimana dikutip Azwar, S (1988), menyebutkan ada tiga proses sosial yang mempengaruh perubahan sikap, yakni 1) Kesediaan, yaitu ketika individu menerima pengaruh karena berharap memperoleh tanggapan positip dari pihak lain. 2) Identifikasi, yaitu terjadi apabila individu meniru sikap seseorang sikap tersebut sesuai dianggapnya sebagai hubungan yang menyenangkan. 3) Internalisasi, terjadi apabila individu 
menerima pengaruh itu karena sikap tersebut sesuai dengan sistem nilai yang dianutnya.

Dari pendapat-pendapat di atas dapat ditarik kesimpulan bahwa sikap adalah keadaan dalam diri manusia yang menggerakkan untuk bertindak, menyertai manusia dengan perasaan-perasaan tertentu dalam menanggapi objek dan terbentuk atas dasar pengalaman-pengalaman. Dalam kaitannya dengan sikap terhadap pekerjaan, Simanjuntak, P (1968) menyatakan bahwa seseorang yang memiliki sikap kerja yang baik biasanya memiliki ciri-ciri sebagai berikut : a) Mengerjakan tugas yang dibebankan dengan tuntas. b) Mengutamakan pencapaian tujuan dan produktivitas. c) Berani mengakui kesalahannya dan bersedia memperbaikinnya.

\section{Metode Penelitian}

Populasi dalam penelitian ini adalah para pembimbing mahasiswa dari pihak industri yang melakukan PKLI pada priode tahun 2013 dan 2014. Brdasarkan data yang ada di Jurusan Pendidikan Teknik Mesin FT Unimed terdapat 25 responden dari 25 perusahaan/industri/bengkel, dan ke 25 responden tersebut seluruhnya dijadikan sebagai sempel.

Sesuai dengan permasalahan yang akan diungkap, maka penelitian ini termasuk penelitian "Ekspost Facto" Penelitian ini tidak membuat perlakuan untuk mengontrol ubahan, melainkan hanya mengungkapkan fakta berdasarkan pengukuran atau penilaian dari para responden mengenai kemampuan yang dimiliki peserta praktek industri. Dengan demikian data dalam penelitian ini adalah berwujud data kualitatif. Untuk menjaring data-data penelitian digunakan angket.

Data yang telah dikumpul selanjutnya ditabulasi dan dilakukan perhitungan sesuai dengan analisis deskriftif kuantitatif. Dalam hal ini pihak responden diminta memberikan tanggapan pada setiap item dengan dua alternatif. Alternatif A berarti mahasiswa sudah memiliki kreteria atau aspek dari kemampuan kerja yang baik, sedangkan alternatif B berarti mahasiswa masih kurang memiliki kriteria atau aspek dari kemampuan kerja. Selanjutnya interprestasi data hasil penelitian dilakukan dengan melihat kecenderungan (persentase) dari penilaian pihak industri terhadap butir-butir yang mencerminkan aspek kemampuan kerja dari instrumen yang digunakan dalam penelitian. Untuk lebih jelasnya mengenai hal tersebut ditentukan kriteria sebagai berikut (tabel 1)

Tabel 1. Penilaian Para Pembimbing dari Industri

\begin{tabular}{|c|c|}
\hline $\begin{array}{lr}\text { Persentasi } & \text { penilaian } \\
\text { pembimbing } & \text { praktek } \\
\text { industri r yang } & \text { menyatakan pendapat. } \\
\end{array}$ & Kategori \\
\hline $\begin{array}{l}100 \%-90 \% \\
86 \%-80 \% \\
79 \%-70 \% \\
69 \%-60 \% \\
59 \% \text { ke bawah }\end{array}$ & $\begin{array}{l}\text { Baik Sekali } \\
\text { Baik } \\
\text { Cukup } \\
\text { Kurang/Rendah } \\
\text { Kurang Sekali }\end{array}$ \\
\hline
\end{tabular}

Hasil penelitian

Berdasarkan hasil analisis data, maka dapat diberikan gambaran sebagai berikut :

1. Pengetahuan Kerja 
Untuk tingkat pengetahuan kerja mahasiswa, berdasarkan penilaian para pembimbing dapat diketahui bahwa $28 \%$ mereka mengatakan mahasiswa masih kurang mampu, sedangkan $72 \%$ dari para pembimbing mengatakan, mahasiswa peserta PKLI telah memiliki pengetahuan kerja yang cukup baik. Untuk jelasnya dapat dilihat pada tabel 2 berikut ini.

\begin{tabular}{|c|c|c|c|}
\hline \multirow{2}{*}{$\begin{array}{c}\text { Nomor } \\
\text { Item }\end{array}$} & \multicolumn{2}{|c|}{ Penilaian } & \multirow{2}{*}{ Jumlah } \\
\cline { 2 - 3 } & $\mathbf{A}$ & $\mathbf{B}$ & \\
\hline 1 & 21 & 4 & 25 \\
\hline 2 & 18 & 7 & 25 \\
\hline 3 & 17 & 8 & 25 \\
\hline 4 & 15 & 10 & 25 \\
\hline 20 & 19 & 6 & 25 \\
\hline Total & $\mathbf{9 0}$ & $\mathbf{3 5}$ & $\mathbf{1 2 5}$ \\
Persen & $\mathbf{7 2}$ & $\mathbf{2 8}$ & $\mathbf{1 0 0}$ \\
\hline
\end{tabular}

\section{Kreativitas Kerja}

Data hasil penelitian dari aspek kreativitas kerja dapat dilihat pada tabel 3 berikut ini :

Tabel 3. Penilaian terhadap kreatvitas Kerja mahasiswa peserta PKLI.

\begin{tabular}{|c|c|c|c|}
\hline \multirow{2}{*}{$\begin{array}{c}\text { Nomor } \\
\text { Item }\end{array}$} & \multicolumn{2}{|c|}{ Penilaian } & \multirow{2}{*}{ Jumlah } \\
\cline { 2 - 3 } & $\mathbf{A}$ & $\mathbf{B}$ & \\
\hline 13 & 6 & 19 & 25 \\
\hline 14 & 17 & 8 & 25 \\
\hline 15 & 16 & 9 & 25 \\
\hline 16 & 14 & 11 & 25 \\
\hline Total & $\mathbf{5 3}$ & $\mathbf{4 7}$ & $\mathbf{1 0 0}$ \\
Persen & $\mathbf{5 3}$ & $\mathbf{4 7}$ & $\mathbf{1 0 0}$ \\
\hline
\end{tabular}

Dari table 3 di atas dapat diketahui bahwa $53 \%$ para pembimbing mengatakan kreativitas kerja mahasiswa pesera PKLI adalah baik dan $47 \%$ pembimbing mengatakan masih kurang baik.

3 Kecepatan Kerja

Data hasil penelitian dari aspek kecepatan kerja dapat dilihat pada tabel 4 berikut ini :

Tabel. 4. Penilaian Terhadap Kecepatan Kerja mahasiswa PKLI.

\begin{tabular}{|c|c|c|c|}
\hline \multirow{2}{*}{$\begin{array}{c}\text { Nomor } \\
\text { Item }\end{array}$} & \multicolumn{2}{|c|}{ Penilaian } & \multirow{2}{*}{ Jumlah } \\
\cline { 2 - 3 } & $\mathbf{A}$ & $\mathbf{B}$ & \\
\hline 5 & 19 & 6 & 25 \\
\hline 6 & 20 & 5 & 25 \\
\hline 7 & 16 & 11 & 25 \\
\hline 8 & 13 & 12 & 25 \\
\hline Total & $\mathbf{6 8}$ & $\mathbf{3 2}$ & $\mathbf{1 0 0}$ \\
Persen & $\mathbf{6 8}$ & $\mathbf{3 2}$ & $\mathbf{1 0 0}$ \\
\hline
\end{tabular}

Dari tabel 4 di atas dapat diketahui bahwa $68 \%$ para pembimbing dari pihak industri mengatakan, kecepatan kerja mahasiswa peserta PKLI sudah baik, namun $32 \%$ pembimbing dari pihak industri mengatakan kecepatan kerja mahasiswa masih kurang baik.

4 Kualitas Pekerjaan

Dari aspek kualitas kerja, data mahasiswa peserta PKLI dapat dilihat pada tabel 5

Tabel 5. Penilaian Terhadap Kualitas Hasil Kerja Mahasiswa Peserta PKLI.

\begin{tabular}{|c|c|c|c|}
\hline \multirow{2}{*}{$\begin{array}{c}\text { Nomor } \\
\text { Item }\end{array}$} & \multicolumn{2}{|c|}{ Penilaian } & \multirow{2}{*}{ Jumlah } \\
\cline { 2 - 3 } & $\mathbf{A}$ & $\mathbf{B}$ & \\
\hline 9 & 21 & 4 & 25 \\
\hline 10 & 11 & 14 & 25 \\
\hline 11 & 19 & 6 & 25 \\
\hline 12 & 16 & 9 & 25 \\
\hline Total & $\mathbf{6 7}$ & $\mathbf{3 3}$ & $\mathbf{1 0 0}$ \\
\hline
\end{tabular}




\begin{tabular}{|l|l|l|l|}
\hline Persen & 67 & 33 & 100 \\
\hline
\end{tabular}

Dari tabel 5 diketahui bahwa $67 \%$ dari pembimbig praktek industri mengatakan kualitas pekerjaan mahasiswa dalam kategori baik, sedangkan 33\% mengatakan bahwa kualitas pekerjaan mahasiswa peserta PKLI masih kurang baik.

\section{Disiplin dan Sikap Kerja}

Dari aspek disiplin dan sikap kerja mahasiswa peserta praktek kerja industri sesuai dengan penilaian pembimbing praktek, dapat dilihat pada tebel 6 berikut ini.

Tabel 6. Penilaian Terhadap Disiplin Dan Sikap Kerja Mahasiswa Peserta PKLI

\begin{tabular}{|c|c|c|c|}
\hline \multirow{2}{*}{$\begin{array}{c}\text { Nomor } \\
\text { Item }\end{array}$} & \multicolumn{2}{|c|}{ Penilaian } & \multirow{2}{*}{ Jumlah } \\
\cline { 2 - 3 } & $\mathbf{A}$ & $\mathbf{B}$ & \\
\hline 17 & 17 & 8 & 25 \\
\hline 18 & 19 & 6 & 25 \\
\hline 19 & 15 & 10 & 25 \\
\hline 21 & 10 & 15 & 25 \\
\hline Total & $\mathbf{6 1}$ & $\mathbf{3 9}$ & $\mathbf{1 0 0}$ \\
Persen & $\mathbf{6 1}$ & $\mathbf{3 9}$ & $\mathbf{1 0 0}$ \\
\hline
\end{tabular}

Dari tabel 6 di atas dapat diketahui persentase yang memberikan penilaian baik dan kurang oleh para pembimbing praktek industri untuk masing-masing butir. Namun untuk keseluruhan dapat dijelaskan bahwa $61 \%$ pembimbing mengatakan para mahasiswa peserta praktek industri adalah baik, dan 39\% mengatakan masih kurang.

Berdasarkan hasil analisis pada tiap-tiap aspek diatas, maka secara keseluruhan kecenderungan kemampuan kerja mahasiswa peserta praktek kerja lapangan industri Jurusan Pendidikan Tenik Mesin FT Unimed Medan priode tahun 2013 dan 2014 sesuai dengan penilaian para pembimbing praktak dari pihak industri dapat dilihat pada tabel 7 berikut ini :

Tabel 7. Kecenderungan Kemampuan Kerja Mahasiswa Praktek Kerja Lapangan Industri

\begin{tabular}{|l|c|c|}
\hline $\begin{array}{c}\text { Aspek Kemampuan } \\
\text { Kerja }\end{array}$ & $\begin{array}{c}\text { Kecenderungan } \\
\text { (Persentase) }\end{array}$ & $\begin{array}{c}\text { Interpretasi } \\
\text { / Kriteria }\end{array}$ \\
\hline 1. Pengetahuan Kerja & 72 & Cukup \\
2. Kreativitas Keja & 53 & Kurang \\
3. Kecepatan Kerja & 68 & Kurang \\
4. Kualitas Kerja & 67 & Kurang \\
5. Disiplin/Sikap & 61 & Kurang \\
\hline Kerja & 64,20 & Kurang \\
\hline \multicolumn{1}{|c|}{ Rerata } & \\
\hline
\end{tabular}

Dari tabel 7 diatas dapat diketahui bahwa rata-rata kecenderungan (persentase) penilaian pihak industri terhadap kemampuan kerja mahasiswa peserta praktek kerja lapangan industri adalah 64,20\% Dari hasil perhitungan ini dapat disimpulkan bahwa kemampuan kerja mahasiswa peserta praktek kerja lapangan industri Jurusan Pendidikan Teknik Mesin FT Unimed berada dalam kategori kurang oleh pihak industri.

\section{Pembahasan}

Praktek kerja lapangan industri (PKLI) merupakan wahana yang sangat penting dalam rangka menambah wawasan yang mencakup ranah kongnitif, afektif, maupun psikomotorik bagi para mahasiswa dalam kaitannya dengan dunia kerja yang sebenarnya. Bertambahnya wawasan dan pengalaman nyata yang diperoleh di industri akan sangat berguna dalam mengembangkan dirinya sebagai tenaga kependidikan, apalagi bagi mereka yang akan terjun kedunia industri. Kegiatan yang mereka lakukan 
selama praktek industri akan mencerminkan kemampuan mereka masing-masing dan secara langsung dapat diketahui oleh pihak industri, dengan demikian PKLI dapat berfungsi sebagai media untuk memasarkan lulusan FT Unimed khususnya di dunia industri.

Sejalan dengan hal diatas, dari hasil penelitian ini ditemukan bahwa dari lima aspek yang mencerminkan kemampuan kerja mahasiswa di industri selama praktek, baru satu, yaitu aspek pengetahuan kerja dinyatakan sudah cukup oleh pihak industri. Sedangkan 4 (empat) aspek lainnya masih dinilai kurang, yaitu aspek kreativitas kerja, kualitas kerja, kecepatan kerja serta disiplin dan sikap kerja, Dari hasil penilaian dapat diketahui bahwa kegiatan belajar di Jurusan Teknik Mesin FT Unimed terutama yang berkaitan langsung dengan dunia kerja (industri) masih perlu ditingkatkan. Untuk aspek pengetahuan kerja yang meliputi, teori tentang bahan, alat-alat tangan dan alat ukur, gambar kerja, teori kerja mesin, kerja plat las dan tempa. Mengingat hasil ini belum juga optimal sementara perkembangan ilmu dan teknologi dewasa ini sangat cepat, maka meningkatan aspek-aspek ini mutlak diperlukan.

Kekurangan pada aspek yang lain yakni aspek kualitas kerja, kecepatan kerja, aspek kreativitas kerja, tampaknya terpengaruh dari aspek yang lain, yaitu pengetahuan kerja. Dari hasil wawancara peneliti dengan responden dapat diketahui bahwa kelemahan istilah-istilah di industri yang kadangkadang jauh berbeda dengan yang dikenal selama di bangku kuliah, dapat menyulitkan peserta PKLI disamping penyesuaian diri dengan peralatan-peralatan yang ada. Aspek kreativitas kerja diketahui hanya 53\% pihak industri yang menyatakan baik, sedangkan 47\% menyatakan masih rendah (kurang). Hal ini mempertegas bahwa kurangnya pengetahuan kerja akan sangat membatasi kreativitas kerja. Untuk disiplin kerja sesuai dengan wawancara peneliti dengan beberapa orang pihak industri menyatakan, mahasiswa yang tidak masuk pada hari praktek, tidak berupaya menggantinya pada hari yang lain, demikian juga jam masuk dan jam keluar sering kali tidak sesuai dengan jam kerja yang ada diindustri, Di samping itu sebagian dari mahasiswa kurang menyadari modal pengalaman dari para pekerja di industri walaupun pendidikannya lebih rendah, namun sangat bermanfaat memberikan kemampuan kerja yang baik.

Faktor lain yang mempengaruhi kedisiplinan mereka menurut pihak industri adalah meninggalkan praktek (kerja) dengan alasan mengikuti kuliah di kampus. Oleh karena itu ada pihak industri yang mengusulkan agar mahasiswa yang praktek kerja industri paling tidak berlangsung selama 6 bulan. Nmaun ini merupakan hal yang cukup mendasar dan perlu dipertimbangkan oleh pihak Jurusan Teknik Mesin sebab sangat terkait pada kurikulum. Kurikulum sekolah tidak mungkin memperbaharui tiap tahun, sementara ilmu dan teknologi berkembang dengan pesat, yang mengakibatkan pendidikan tidak mampu menghasilkan tenaga kerja yang siap pakai sesuai dengan tuntutan dunia kerja.

Mencermati kembali hasil penelitian ini, dimana penilaian pihak industri terhadap kemampuan kerja mahasiswa peserta PKLI masih kurang, adalah suatu tantangan yang cukup berat bagi Jurusan untuk membenahi diri. Ini sangat diperlukan untuk membangun kepercayaan dunia industri 
mengingat peluang untuk menjadi guru sudah mulai tutup. Membangun kepercayaan pihak industri bukanlah suatu hal yang mudah. Namun dituntut kesediaan dan dedikasi yang cukup tinggi dari semua unsur yang terkait di lembaga FT Unimed mendayagunakan secara optimal segala sistem yang ada. Dengan demikian diharapkan kemampuan kerja lulusan akan mendapat tempat di hati para pengguna lulusan itu sendiri. Menurut Slamet, PH (1990) agar kepercayaan pihak pengguna lulusan terhadap kemampuan kerja para lulusan timbul, maka setiap lulusan harus memiliki beberapa faktor antara lain : sadar IPTEK, kreatif, prakarsa, solidaritas-etis, kemandirian beridealisme, padat pengetahuan, dan berfikir kritis, Agar hal ini dapat terwujud, kerja keras pihak lembaga FT Unimed harus benar benar menyadari tugasnya masing-masing. Dosen pembimbing praktek industri yang selama ini jarang terjun ke lapangan melihat perkembangan mahasiswa, harus diupayakan agar benar-benar melihat kenyataan yang ada di lapangan industri. Kemudian mahasiswa jangan sampai difokuskan kepada seorang dosen pembimbing saja.

Kurangannya kemampuan kerja dari mahasiswa sebagaimana terungkap dalam hasil penelitian ini. dimungkinkan juga oleh pihak industri sendiri kurang memberikan kesempatan kepada para mahasiswa peserta praktek industri, sehingga mahasiswa kurang dapat mengembangkan kemampuan. Menurut Simanjuntak P (1986) salah satu hal yang dapat menentukan produktivitas kerja seseorang adalah adanya kesempatan mengembangan diri. Kesempatan tersebut akan mendorong tinmbulnya kretivitas. Sejalan dengan hal tersebut maka hasil penelitian ini yang cenderung mengatakan bahwa kemampuan kerja mahasiswa praktek industri "kurang", harus ditanggapi dengan bijaksana dengan cara mengaktifkan fungsi dosen pembimbing untuk selalu berkonsultan dengan pihak industri.

\section{Kesimpulan}

Dari hasil analisis data, maka hasil penelitian ini dapat disimpulkan sebagai berikut

1. Aspek pengetahuan kerja mahasiswa peserta praktek industri berada dalam kategori cukup.

2. Aspek kreativitas kerja mahasiswa peserta praktek kerja industri berada dalam taraf kurang/rendah.

3. Aspek kecepatan kerja mahasiswa peserta praktek kerja industri berada dalam kategori rendah.

4. Aspek kualitas kerja mahasiswa peserta praktek kerja industri berada dalam kategori rencah

5. Aspek disiplin dan sikap kerja mahasiswa peserta praktek kerja industri berada dalam kategori kurang/rendah.

6. Secara keseluruhan kemampuan kerja mahasiswa peserta praktek kerja industri dinilai masih kurang oleh pihak industri.

\section{Saran}

Berdasarkan kesimpulan yang diperoleh dari hasil penelitian ini maka beberapa hal dapat disarankan yakni sebagai berikut :

1. Masih perlu meningkatkan penguasaan terhadap materi kuliah terutama yang terkait langsung dengan praktek kerja industri.

2. Penanaman disiplin dan semangat kerja yang tinggi.

3. Pengawasan dan kunjungan langsung secara rutin oleh dosen pembimbing ketempat mahasiswa di mana mahasiswa melakukan praktek industri

4. Perlu mengkaji ulang jangka waktu pelaksaan praktek industri, agar benar-benar berdaya guna bagi peserta PKLI. 
5. Membatasi mahasiswa yang mengambil mata kuliah praktek kerja industri hanya pada mereka yang tinggal beberapa mata kuliah dengan hari-hari pelaksanaan praktek industri.

\section{Daftar Pustaka}

Amien, Moh. (1980). Peranan Kreativitas Dalam Pendidikan Pidato Dies Natalls IKIP Yogyakarta.

Azwar, Saifuddin. (1988). Sikap Manusia Teori dan Pengukurannya. Yogyakarta : Librty.

Bower, Gordon H. And Hilgard. (1981). Theories of Learning. Englewood Cliffs, New Jersey : Prentice Hall, Inc.

Braden, Paul V., James,L. (1970). Occupational Training Informations Oklahama : Stillwater.

Djoemadi. (1988). Relevansi Kurikulum STM Jurusan Konstruksi Mesin Dengan Pelajaran Industri Logam Yogyakarta : P2 IKIP Yogyakarta.

Edward. (1982). Cara Mengklasifikasikan Kemampuan. Padang : FPTK IKIP Padang.

Goodwin, William L. (1975). Facilitating Student Learning. New York : Harper \& Row Publisher.

Leighbody, L. (1968). Method of Teaching Shop and Tachnical Subjects. New York : Delmar Publisher.

Ravianto, J. (1985). Produktivitas dan Teknologi. Jakarta : SIUP.

Simanjuntak, P. (1985). Produktivitas dan Mutu Kehidupan. Jakarta : SIUP

Slamet, PH. (1990). Kesiapan Lulusan FPTK IKIP Yogyakarta Untuk Mampu Bekerja Di bidang Pendidikan Formal dan Non Formal. Pengembangan FPTK IKIP Yogyakarta 20 Agustus 1999.

Sugiyono. (1990). Model Alternatif Sistem dan Pengembangan Management Pendidikan Untuk Menyiapkan Tenaga Kerja Industri Permesinan. Desertasi. IKIP Bandung

Wetik, J. (1996). Penelitian Kerja dan Produktivitas. Jakarta Erlangga.

Penilaian pihak industri terhadap tingkat kemampuan kerja mahasiswa -130 